\title{
Does spatial and seasonal variability in fleshy-fruited trees affect fruit availability? A case study in gallery forests of Central Brazil
}

\section{Adriano Antonio Brito Darosci* (D), Frederico Scherr Caldeira Takahashi ${ }^{2}$ (D), Carolyn Elinore Barnes Proença ${ }^{3}$ (D), Lucia Helena Soares-Silva ${ }^{3}$ (1) and Cássia Beatriz Rodrigues Munhoz ${ }^{3}$ (1)}

Received: August 31, 2020

Accepted: January 11, 2021

\begin{abstract}
Forest stands in seasonal environments can differ spatially and seasonally in the diversity of fleshy fruits available as resources for fauna. The aim of this study was to quantify spatial and seasonal variation in the richness and abundance of the dominant fleshy-fruited tree species in gallery forests of the Cerrado domain. Tree species composition and abundance were compiled from the literature for 10 gallery forest stands. Data were interpolated and extrapolated by the sample coverage method, using Hill numbers to determine the typical species as well as the most abundant species in each fruiting season. Stands differed in the occurrence of fleshy-fruited tree species and in the number of fleshy-fruited tree individuals. Probabilities for the occurrence of fleshy fruit were similar between in the wet and dry. However, across all stands, species that fruit primarily in the dry season were less common than those that fruit in the wet season. The sharing of fleshy-fruited tree species was low and the most abundant species differed among the studied stands. Fleshy fruits were available all year round and periods of high fruit availability are highly synchronized while periods of low fruit availability were much less so.
\end{abstract}

Keywords: abundance, Cerrado, food phenology, frugivory, fruiting, plant-animal interactions, ornithocory, resources

\section{Introduction}

The diversity of fleshy-fruited trees (i.e., plants with fleshy fruits or other fleshy parts such as arils that attract animals) in plant communities can be highly heterogeneous, even within the same region (López-Martínez et al. 2013). Forest stands with greater forest cover tend to be richer in fleshy-fruited plant species and to produce more fleshy fruit biomass (Pessoa et al. 2016). Seed dispersal by frugivores may also result in variation in the structure and dynamics among plant communities (Wright et al. 2005; Morales et al. 2013). Therefore, data on the richness and abundance of fleshy-fruited plant species within tree communities can contribute to a better understanding of the relationship between vegetation structure and dispersal processes (Wang \& Smith 2002).

The spatial distribution of floristic diversity is important to the diet of animals that range over large areas, which leads to the sharing of a disperser fauna among different forests. For example, forests in fragmented landscapes that differ in abundance of fleshy- fruited tree species may be connected by foraging frugivorous birds in search of resources, thus affecting seed dispersal across forest fragments (Emer et al. 2018). Since different tree species have different fruiting

1 Instituto Federal de Educação Ciência e Tecnologia Goiano, 73900-000, Posse, GO, Brazil

2 Instituto Brasileiro de Geografia e Estatística, 70312-970, Brasília, DF, Brazil

3 Departamento de Botânica, Campus Darcy Ribeiro, Universidade de Brasília, 70910-900, Brasília, DF, Brazil

* Corresponding author: adriano.darosci@ifgoiano.edu.br 
seasons, the quality and quantity of resource availability can vary seasonally (Staggemeier et al. 2017). Fruiting seasonality is thought to promote seed and seedling survival by reducing predation (Wright et al. 2005) and may improve seed dispersal efficiency (Karr 1976). Fruiting when resource availability is low increases the attraction of frugivores (Darosci et al. 2017). In addition, frugivores may forage over large areas during times of scarcity, thereby transporting plant diaspores over long distances (Blendinger et al. 2012; Emer et al. 2018).

The dry savanna regions of Central Brazil (Cerrados) are cut by rivers and streams creating linear strips of gallery forest. Gallery forests support high tree species richness and an associated fauna (Kuhlmann \& Ribeiro 2016). Floristic differences among gallery forests can result from environmental characteristics such as soil, flooding, waterlogging, relief and geomorphology (OliveiraFilho 1989; Veneklaas et al. 2005), and increasingly from differing land use and disturbance histories. These factors vary spatially and contribute to floristic differences among areas that increase with distance (Condit et al. 2002). In continuous tropical forests, despite the high diversity of trees, a few hyper-dominant species frequently account for a large proportion of individuals (Staggemeier et al. 2017). These species may be present in many different forests but be hyper-dominant locally (ter Steege et al. 2013). Structural and floristic changes are also found among stands of gallery forests on a regional scale (Silva-Júnior et al. 2001; Veneklaas et al. 2005). In the Cerrado, rainfall seasonality is pronounced, with a dry season (average rainfall $<200 \mathrm{~mm}$ ) between May and September and a wet season (average rainfall $1500 \mathrm{~mm}$ ) between October and April (Silva et al. 2008). Marked seasonality of rainfall in the region is believed to drive patterns of fruit production in gallery forests, which support a high diversity of fruits and frugivores (Kuhlmann \& Ribeiro 2016).

A broad understanding of the frugivory-seed dispersal process depends on both within- and between-community analyses, but few studies have adopted this approach (e.g., Almeida-Neto et al. 2008; Maruyama et al. 2019). Additionally, few studies have considered the abundance of dispersal modes among plant communities (Correa et al. 2015) and have instead focused only on species richness, thus limiting the acquisition of information regarding the resources available for fauna (Jara-Guerrero et al. 2011). Spatial floristic heterogeneity and fruiting seasonality may result in differences in the distribution and abundance of resources among sites and between seasons (Maruyama et al. 2019), and more studies that relate environmental seasonality to fruiting season based on records collected over time are needed (Polansky \& Boesch 2013). One study that addressed plant phenology under the Cerrado's highly seasonal rainfall has suggested that most gallery forest species tended to fruit in the wet season, although the most abundant species fruit all year round (Gouveia \& Felfili 1998). However, in that study a single gallery forest stand was studied. Another study with 15 plant species found a slight majority of plant species from forest habitats fruiting during the dry season (Maruyama et al. 2019).

The core region of the Cerrado domain is currently represented by numerous patches of native vegetation in isolated protected areas surrounded by a matrix of highly modified rural, urban and periurban areas (Alencar et al. 2020). In the fragmented landscape of this highly threated domain, it is of particular interest to understand the spatial and seasonal abundance of fleshy-fruited trees, a potential food source for the local frugivores.

We hypothesized that because gallery forests present low species similarity among sites (Silva-Júnior et al. 2001) and fleshy-fruited tree species can comprise $73-86 \%$ of tree species in these forests (Kuhlmann \& Ribeiro 2016) resources available to the fauna would differ spatially following species composition, species abundance and seasonal fruit availability. We tested the following hypotheses: 1) Gallery forest sites differ from one another in composition and abundance of fleshy-fruited trees and this difference is due to the distance between the sites; 2) Gallery forest sites differ from one another in seasonality of fleshy-fruit availability; 3) Trade-offs operate between species composition, species abundance and species seasonality that tend to maintain year-round availability of fleshy fruits at landscape scale.

\section{Materials and methods}

\section{Data collection}

Abundance data for tree species of 10 gallery forest stands (each representing a different site) were compiled from the literature (Fig. 1; Tab. S1 in supplementary material). All ten sites were sampled between 1986 and 2013 (i.e., time lapse of data collection was ignored in the analysis). The studies were carried out in gallery forests stands in the Distrito Federal, in Brazil (15 47'30" S; $47^{\circ} 53^{\prime} 23^{\prime \prime} \mathrm{W}$ ), at an altitudinal range of 900-1,000 $\mathrm{m}$ a.s.l. In the Cerrado region of Brazil gallery forests form paths of tropical rainforest immersed in the tropical savanna vegetation on the fringes of narrow water courses, such as along streams and around springs. According to Köppen's classification, the climate of the region is Aw, with two well-defined seasons: a rainy summer (October to April) and a dry winter (May to September). The mean annual temperature of the region varies between 20 and $26^{\circ} \mathrm{C}$ (Eiten 1972). Annual average precipitation is about 1,400 $\mathrm{mm}$ (Borges et al. 2014). All gallery forest areas in this study, except GF2, GF7 and GF8, are included in protected sites (i.e., public or private conservation units) and most of them are surrounded by farms and cities.

We included studies that recorded trees with a diameter at breast height (DBH) greater than or equal to $5 \mathrm{~cm}$ (i.e., a pattern followed by most floristic studies done in the 


\section{Adriano Antonio Brito Darosci, Frederico Scherr Caldeira Takahashi, Carolyn Elinore Barnes Proença, Lucia Helena Soares-Silva and Cássia Beatriz Rodrigues Munhoz}

region). The study region, which encompasses approximately $6,000 \mathrm{~km}^{2}$, possesses high tree species richness with 1,268 species (Proença et al. 2001), representing $68 \%$ of the woody flora of the Cerrados domain (Mendonça et al. 2008).

We compiled data for the trees of each forest stand for species, family, number of individuals and diaspore dispersal syndrome (i.e., the probable dispersal agent according to fruit and seed characteristics). Individuals that were only identifiable to the level of family or genus were excluded, with the exception of genera that were recorded only once in a single forest, since the same genus recorded in two or more forests may or may not belong to the same species. Subspecies and varieties were grouped under their respective species.

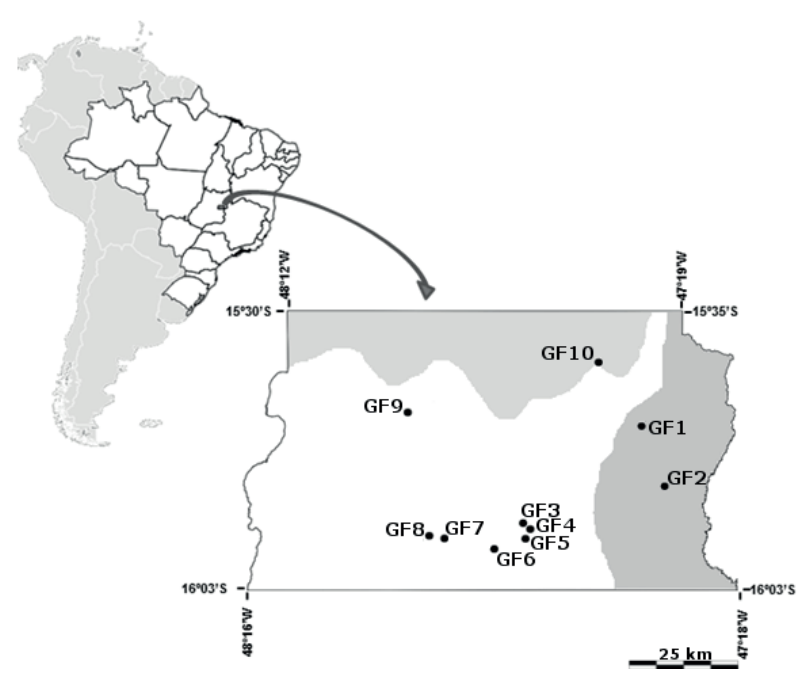

Figure 1. Geographic locality of the 10 surveyed gallery forests in the Distrito Federal, Brazil. Watersheds: Tocantins-Araguaia (light grey, at the top); São Francisco (dark grey, on the right); Paraná (white). The straight-line distance between the forests varies from approximately 0.5 to $54 \mathrm{~km}$. (Scale=1:1,193,000). For further details of the gallery forests (GF1, etc.) see Table S1 in supplementary material.

The diaspore dispersal syndromes of the compiled species were obtained from the literature (Oliveira \& Paula 2001; Pinheiro \& Ribeiro 2001; Kuhlmann \& Ribeiro 2016) and the web database available in Flora Brasiliensis (http:// florabrasiliensis.cria.org.br/; accessed on 30 July 2020). The species were classified as zoochoric (i.e., fleshy-fruited species) or non-zoochoric (Pijl 1982), with the former being divided into ornithochoric (i.e., species with small, colourful against green foliage and less scented diaspores) and nonornithochoric (Valenta \& Nevo 2020).

\section{Data analysis}

Comparisons among areas: species richness, diversity and composition of the most abundant fleshy-fruited trees

Since sample sizes differed among the sites, they were compared under the same completeness of sample (i.e., sample coverage) by interpolation or extrapolation. This method is generally considered to be less sensitive to large sample size or when comparing different sample sizes or sampling methods (Chao et al. 2014). Diversity curves as a function of coverage are used to compare the diversity of different sites, thus standardizing the estimates. For extrapolation we used the abundance matrix of each species (columns) in each forest stand (rows) and obtained richness and diversity estimates as Hill numbers. These values can be compared and expressed in different units of abundance: $q=0$ corresponds to species richness (i.e., it does not consider abundance); $q=1$ corresponds to the exponential of Shannon's entropy index (i.e., it gives rare and abundant species the same weight); and $q=2$ corresponds to the inverse of the Simpson concentration (i.e., it gives rare species low weight) (Chao et al. 2014).

Typical tree species (fleshy-fruited or not) of each forest stand were obtained by ranking them by their abundance and then selecting them according to the number of species using Hill diversity $q=1$ (with coverage of 0.98) (Tab. S2 in supplementary material). Nonmetric multidimensional scaling (NMDS) was used to order the sites in multidimensional space in terms of fleshy-fruited tree species abundance, which represent possible resources available to the fauna in each forest, we applied the Hellinger transformation on the species abundance matrix and then performed NMDS using the Bray-Curtis similarity index (Legendre \& Legendre 2012). A Mantel multivariate correlogram with three distance classes (approximately five, 12 and $20 \mathrm{~km}$ ) was calculated to evaluate the occurrence of spatial autocorrelation (Legendre \& Legendre 2012).

\section{Comparison between seasons: fruit availability likelihood}

Differences in fruit availability in forest stands between dry (May to September) and wet (October to April) seasons were evaluated by comparing the richness of abundant fleshy-fruited tree species in each forest stand, after ranking them by abundance and selecting only the abundant species as estimated by Hill diversity $\mathrm{q}=2$ (i.e., abundant ones). Only half the number of individuals of dioecious species was considered (Bierzychudek \& Eckhart 1988) to better represent the possible available food for the fauna in each season. To define the seasons, the months of April and September were considered transitional between wet to dry and dry to wet respectively. The fruiting seasons of the species were obtained from herbarium records available in SpeciesLink (http://splink.cria.org.br; accessed on 2 April 2019) and GBIF (https://www.gbif.org; accessed on April 2 2019) databases, with preference given to records in the Cerrado within two degrees latitude and three degrees longitude from the Distrito Federal to avoid the influence of spatial variation in reproductive phenology. Most records $(5,238$ out of 6,042) originated between 1978 and 2018. The phenological predictability index (PPI) was used to determine the probability of species being in fruit per month 
(Proença et al. 2012). PPI ranges from approximately 0 to 1 , with a given phenological event being more likely to occur as its PPI value approaches 1 . To avoid misestimating the fruiting probabilities, 15 species ( $22 \%$ of the total) with low numbers of unique fruiting events (i.e., unique combination of month and year) in the herbarium record were not considered in the analysis (considering the reliability threshold proposed by Proença et al. (2012) (Tab. S3 in supplementary material).

All analyses were made in R except PPI probabilities. The iNEXT function [(Chao et al. 2014), supplementary material] was used for sample coverage. The vegan package was used for NMDS using the metaMDS function (version 2.5-6; (Oksanen 2011)) and the Mantel correlograms, and the BiodiverstyR package (https://cran.r-project.org/ web/packages/BiodiversityR/index.html) was used for the abundance rankings. PPI calculations were run in BRAHMS v. 7 (Botanical Research and Herbarium Management System (http://dps.plants.ox.ac.uk/bol/). To express monthly variation in resources for frugivores for each gallery forest, monthly PPI values for the main fleshy-fruited species present were multiplied by the relative abundance values of the species in the tree community of each forest stand. These were then added up to provide a value that reflected the likelihood of fruit being available in a stand (henceforth referred to as Fruit Availability Likelihood, FAL). Species in which the maximum PPI value was at least three times that of the minimum PPI value, and occured in different seasons, were classified as seasonal specialists: WET, DRY, transitional WET TO DRY or DRY TO WET. Species that failed these criteria were classified as SEASON NOT DEFINED, e.g., are predicted to be equally probable to fruit either in the wet, dry or transitional seasons.

\section{Results}

The number of fleshy-fruited species and individuals varied among the gallery forest stands (Tab. 1) and the effect of distance on differences in floristic composition among stands, expressed by the Mantel correlogram, was significant for the first two distance classes $(\mathrm{P}<0.05)$. The NMDS ordination showed a continuous gradient of variation in floristic composition. The NMDS ordination separated flooded (or with flooded patches) gallery forest stands GF7, GF8 and GF9 from the other stands on well-drained soils in axis 1 , and geographic distance contributed to the separation among the sites in axis 2 (Fig. 2). Across all stands, $73 \%$ of the species and $81 \%$ of the individuals were classified as zoochoric, with dominance of ornithochoric dispersal. In most of the forests, about $35 \%$ of fleshy-fruited species were dioecious (Tab. 1).

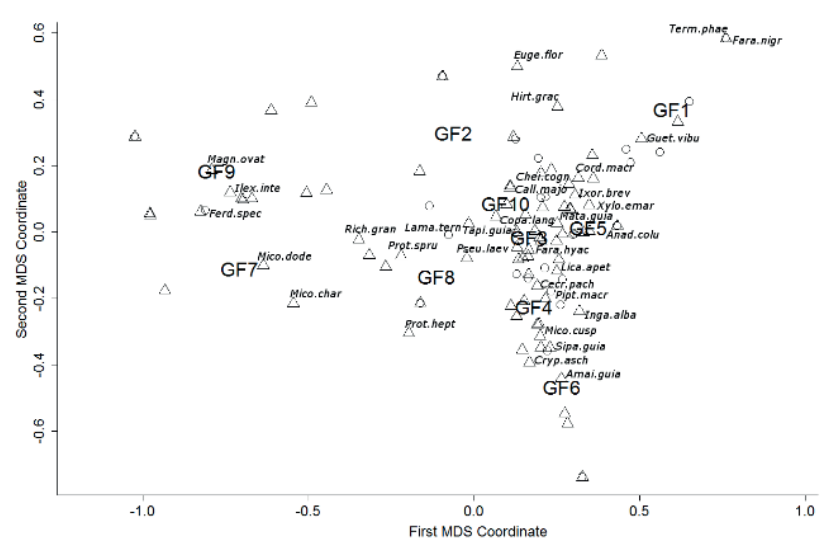

Figure 2. Non-metric multidimensional scaling of the 10 surveyed gallery forests according to the abundance of tree species (Kruskal's stress=6.13). $\Delta=$ zoochoric species; $O=$ non-zoochoric species. Names are provided only for the highly abundant tree species ( $>42 \%$ of the individuals in each gallery forest). For full species names, see Table S2 in supplementary material; for further details of the gallery forests see Table S1 in supplementary material.

Typical species (i.e., according Hill diversity $q=1$ ) invariably showed wide geographical distributions. Most are not endemic to Brazil and occur throughout forested areas of South America (such as in the Atlantic Forest or Amazon Forest); the species with the narrowest distribution found (Protium brasiliense) occurred in Gallery Forests and Atlantic Forest in seven Brazilian states as well as the Distrito Federal; only one (Byrsonima laxiflora) was a Gallery

Table 1. Sample coverage; species number and abundance of zoochoric, zoochoric and dioecious, non-zoochoric and ornithochoric trees in ten forests; and percentage of abundant zoochoric species (see Tab. S3 in supplementary material) with higher chances of fruiting in each of the seasons. Ind.= individuals. Dry to Wet $=$ September, a transition month. Definitions for the abbreviations for the different gallery forests are found in Table S1 in supplementary material.

\begin{tabular}{|c|c|c|c|c|c|c|c|c|c|c|}
\hline & GF1 & GF2 & GF3 & GF4 & GF5 & GF6 & GF7 & GF8 & GF9 & GF10 \\
\hline Coverage (\%) & 96.4 & 97.1 & 97.7 & 98.8 & 97.9 & 98.5 & 99.6 & 98.9 & 99.5 & 97.1 \\
\hline No. zoochoric species (Ind.) & $52(487)$ & $91(854)$ & $77(746)$ & $60(782)$ & $78(634)$ & $64(845)$ & $38(1413)$ & 76 (959) & $39(1375)$ & $77(885)$ \\
\hline$\%$ zoochoric and dioecious species (Ind.) & $30(10)$ & $33(22)$ & $39(28)$ & $32(24)$ & $37(26)$ & $34(34)$ & $50(34)$ & $33(29)$ & $41(23)$ & $42(30)$ \\
\hline \% non-zoochoric species (Ind.) & $37(23)$ & $27(17)$ & $22(22)$ & $25(17)$ & $29(34)$ & $25(16)$ & $10(16)$ & $31(17)$ & $12(23)$ & $26(13)$ \\
\hline \% ornithochoric species (Ind.) & $90(74)$ & $87(86)$ & $88(93)$ & $87(82)$ & $92(89)$ & $86(83)$ & $100(100)$ & $87(93)$ & 97 (99) & $87(89)$ \\
\hline Wet (\%) & 33 & 26 & 26 & 23 & 25 & 19 & 0 & 16 & 8 & 26 \\
\hline Dry (\%) & 8 & 11 & 11 & 11 & 9 & 5 & 0 & 6 & 0 & 4 \\
\hline Dry to Wet (\%) & 0 & 0 & 0 & 4 & 0 & 5 & 0 & 3 & 0 & 0 \\
\hline Both seasons (\%) & 33 & 55 & 42 & 46 & 59 & 48 & 83 & 56 & 67 & 55 \\
\hline
\end{tabular}


Forest specialist (Flora do Brasil 2020 2020). Data samples from all forest stands were considered highly complete (coverage $>95 \%$ ) (Tab. 1). Sharing of the most abundant species was low, with most species being associated with one or a few forest stands, revealing strong floristic differences amongst them (Fig. 3). In addition, in GF1, GF7 and GF9, most individuals belonged to just a few species (Fig. S1 in supplementary material), most of them fleshy-fruited, except Ferdinandusa speciosa and Cedrela odorata that have dry, probably wind dispersed fruits (i.e., non-zoochoric).

Fruiting in both the wet and dry seasons was the most common pattern for the abundant species and fruiting mainly in the dry season was the least common (Tab. 1; Tab. S3 in supplementary material). For example, nearly all abundant species in GF7 had the same chance of fruiting in the wet and dry season while only a few species from GF1 and GF10 had a higher chance of fruiting only in dry season (Tab. 1). Also, the abundant species that had a higher probability of fruiting during the wet season were concentrated in just a few stands (e.g., Cordiera macrophylla, Eugenia florida and Guettarda viburnoides in GF10, GF2 and GF1, respectively) (Fig. 3).

Seasonal variation in fruit availability likelihood (FAL) was more pronounced in some forests (e.g., GF2, GF9 and GF10) than in others (e.g., GF3, GF4 and GF7). The highest values of FAL were invariably recorded during the rainy season (Fig. 4), and the peak FAL month in nine out of the 10 stands was October (the exception was GF1 in which the peak month was March). Low values of FAL followed two slightly different patterns. One group of stands showed a late wet season dip with lowest values of FAL in the transitional month of April (e.g., GF2, GF3, GF4, GF9 and GF10). The other group showed a mid-year dip with lowest values of FAL at the height of the dry season, either June (e.g., GF5 and GF8) or July (e.g., GF1, GF6 and GF7).

\section{Discussion}

\section{Gallery forest spatiality}

We confirmed that gallery forest sites differ from one another in composition and abundance of fleshy-fruited trees and that the difference is influenced to some degree by the distance among the sites. Spatially structured environmental variables can be responsible for differences in forest plant species richness and abundance (Murphy et al. 2015) and be influencing variability in the resources available to the fauna in the 10 studied gallery forests. Environmental heterogeneity is known to increase plant richness (Veneklaas et al. 2005), including fleshy-fruited species (Almeida-Neto et al. 2008; Jara-Guerrero et al. 2011). However, in spite of the significant spatial autocorrelation between forests that we found distance cannot be primarily responsible for the variation in plant richness among areas, as suggested by Oliveira-Filho \& Ratter (1995). In fact, some of the stands were geographically close, in the same watershed and yet had very different floristic compositions. Being located within the same watershed may determine

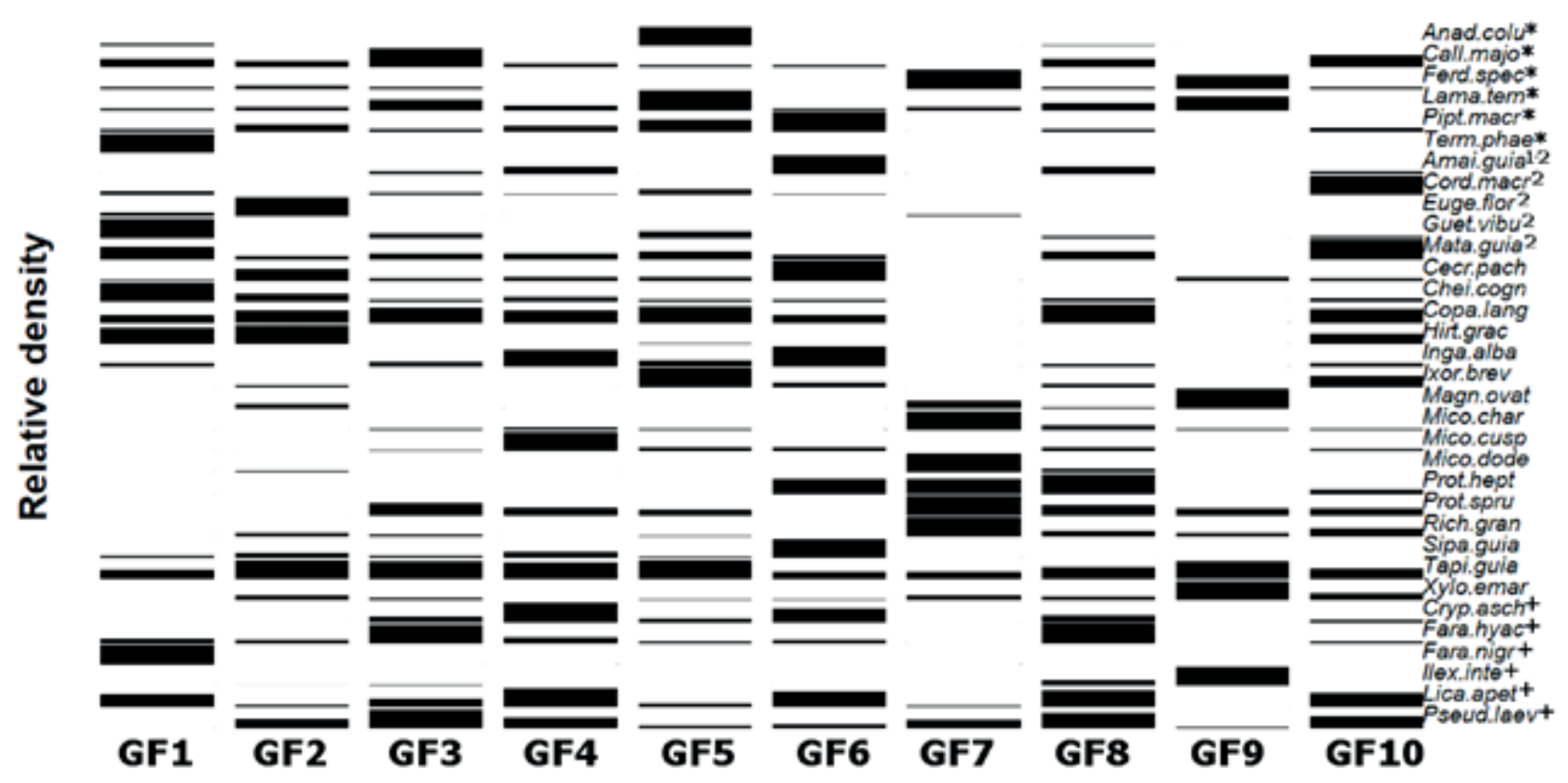

Figure 3. Relative density of the 33 species that ranked 1st-5th most abundant (> $42 \%$ of the individuals in each gallery forest) in the 10 gallery forests. Unmarked species represent zoochoric trees fruiting during both wet and dry season. Marked species: *nonzoochoric; 1-2zoochoric trees fruiting in transition between dry to wet season; 2zoochoric trees fruiting in wet season; +zoochoric trees that were not included in the seasonal analyses due to lack of phenological data. For full species names, see Table S2 in supplementary material; for further details of the gallery forests see Table S1 in supplementary material. 

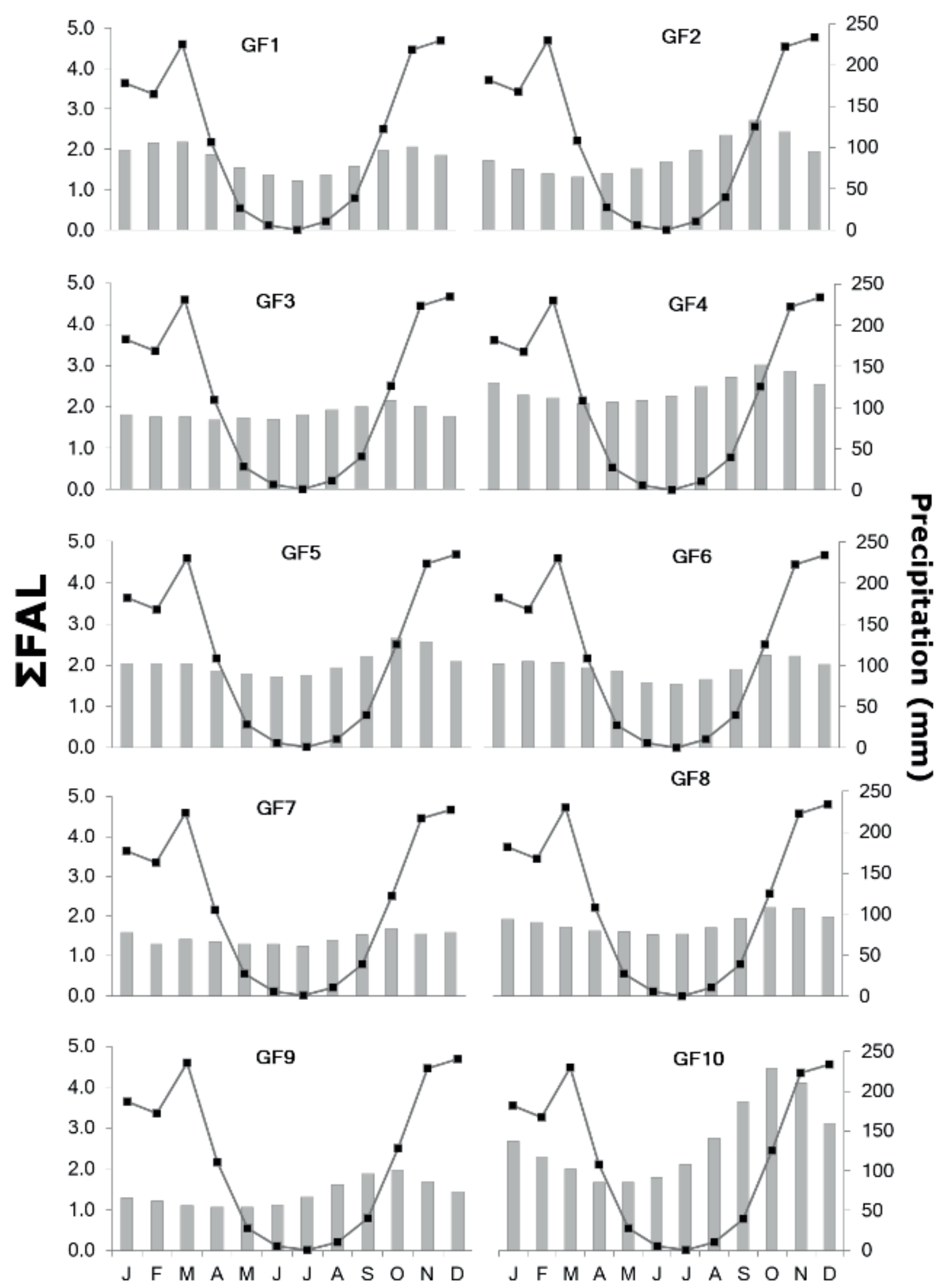

Figure 4. Sum of the fruit availability likelihood (FAL) values (bars) (probability of fruiting (PPI) multiplied by the relative abundance of the species per gallery forest), and average precipitation from 1995 to 2015 (line) (http://www.inmet.gov.br/portal/index.php?r=bdmep/ bdmep, accessed on 5 August 2019). Only zoochoric, abundant species according to the Hill number, $q=2$ were considered. We also considered only half of the individuals of dioecious species to correct for the abundance of individuals in fruiting. For further details of the gallery forests (GF1, etc.) see Table S1 in supplementary material. 


\section{Adriano Antonio Brito Darosci, Frederico Scherr Caldeira Takahashi, Carolyn Elinore Barnes Proença, Lucia Helena Soares-Silva and Cássia Beatriz Rodrigues Munhoz}

floristic and structural similarities among environments (Condit et al. 2002), but local conditions, such as soil properties, may be responsible for differences in plant communities between nearby forests (López-Martínez et al. 2013), as well as random or historic factors.

However, results showed variation in species composition and abundance amongst the stands is most strongly associated with the forest types (i.e., flooded or non-flooded gallery forests). Due to the varied slopes of the terrain, gallery forests have high environmental heterogeneity, including levels of moisture, organic matter and soil nutrients (Oliveira-Filho 1989). Flooded patches of forest, which can lead to high soil moisture, is a determining factor of the floristic variation among gallery forests (Ribeiro \& Walter 2008). It also affects the physical, chemical and biological properties of the soil, resulting in stress to which some species are well-adapted while others are not (Veneklaas et al. 2005). Some species are known to be indicators of flooded environments, such as Ferdinandusa speciosa, Richeria grandis and Xylopia emarginata (Sampaio et al. 2000; Guarino \& Walter 2005). These species were only abundant in a few forests in the present study (GF7 and GF9), which were also those that had a low number of hyper-abundant fleshy-fruited species. The higher or lower percentages of dioecious species amongst fleshy-fruited trees further compounded these differences.

In addition to environmental variables, seed dispersal ability (Wright et al. 2005; Morales et al. 2013) may also influence spatial floristic heterogeneity. The efficiency of seed dispersal by animals, which can connect different areas (Emer et al. 2018), may explain species sharing among distant sites while dispersal limitation may increase dissimilarity among sites that differ in tree species diversity (Murphy et al. 2015). Birds are considered the main frugivores and dispersers in the Cerrado biome (Kuhlmann \& Ribeiro 2016), and their abundance and the variety of their diets are directly related to the richness and abundance of the available fruits (Darosci et al. 2017). Some of these frugivores may to forage in numerous gallery forests to exploit the diversity of fruits (Blendinger et al. 2012) to supplement their diet (Whelan et al. 1998), thus increasing the range of seed dispersal within a region, as was found by Morales et al. (2013). Although fleshy-fruited tree species communities in tropical forests can be limited to just a few hyper-abundant species, these locally abundant species may play an important role as food for frugivores (Stevenson et al. 2015; Staggemeier et al. 2017). Therefore, regional diversity of fleshy-fruited tree species, as well as that of each forest, is important for faunal diversity and conservation. Our results support the idea that gallery forests embedded within a matrix of savanna or isolated in a fragmented or anthropic landscape, show similar patterns to those of continuous tropical forests (Jara-Guerrero et al. 2011; ter Steege et al. 2013; Pessoa et al. 2016): low similarity of fleshy-fruited species between stands, hyperdominance of certain species in some of the stands, with the occasional presence of these hyperdominants as rare or infrequent species in other forests.

\section{Seasonality of gallery forests}

Resources for the fauna are probably available all year round in the studied forests, regardless of the type of forest, as indicated by the high percentage of fleshy-fruited species with similar chances of fruiting in the wet and dry season. In some cases, the correlation between rainfall seasonality and fruit phenology can be weak or negative, and light can be determinant to fruit production (Polansky \& Boesch 2013). Conservative strategies for the exploitation of environmental resources, such as soil moisture, lead some plants to reproduce regardless of the season.

Despite availability of fruit resources, the whole year round, the number of species more likely to fruit during the wet season was higher than species more likely to fruit in the dry season (e.g., GF1 and GF10). From a literature review, $42 \%$ of phenology studies made in seasonally flooded forests - including gallery forests - reported fruiting peaks in the rainy season and $21 \%$ in the dry season. Other studies reported peaks in the transitional periods or the data was not available (Mendoza et al. 2017). Differences in fruit availability among areas and in response to seasonality can cause the fauna to adapt to changes in resource levels (Darosci et al. 2017) or to move among different environments or regions in search of food (Maruyama et al. 2019). Also, some birds exhibit territorial behaviour or low mobility among different areas (Emer et al. 2018), or only include fruits with high nutritional value that are only available at certain times of the year in their diet (Darosci et al. 2017). Thus, some frugivores can be more sensitive to less diverse food availability and be more dependent on local resources in times of scarcity (Maruyama et al. 2019). More studies are necessary to analyse if this is the case in the studied region. Sites that differ in food resource diversity can contribute to feeding the fauna during periods of scarcity, and would thus be considered considered fundamental to the maintenance of frugivore communities (Griz \& Machado 2001). Regardless of the decrease in food availability during the dry season in some forests, Cerrado gallery forests may be less affected by seasonality than other vegetation types, thus receiving the fauna associated with other Cerrado phytophysiognomies during the dry season (Cavalcanti 1992). The difference in the number of fruit consumers between dry and wet seasons may not be apparent at the local scale in the Cerrado (Vieira et al. 2013) because associations between frugivore abundance and temporal and spatial food availability may be only detected at the regional scale (Guitián \& Munilla 2008).

Asynchronous fruiting is common in communities where zoochory predominates as a strategy to avoid competition for frugivores and ensure seed dispersal (Staggemeier et al. 2017). High fruit availability in the same space and at the 
same time is directly correlated to high local bird diversity and competition among fleshy-fruited plants (Darosci et al. 2017). The populations of potential bird dispersers may increase seasonally in some regions of the Cerrado, especially at the beginning of the wet season (Negret 1988), and thus the fruiting season might be conditioned to take advantage of this seasonal increase of seed dispersers. We observed with interest that while periods of high fruit availability likelihood (FAL) were highly synchronized between gallery forests, periods of low FAL were much less so, possibly making frugivore movement between gallery forests more likely during the latter period than the former. As far as we are aware, this is a new finding that has not been previously reported.

\section{Gallery forest year-round fruit availability}

Year-round availability of fleshy fruit seems to be achieved mostly due to the predominance of species that fruit in both wet and dry season across all stands and forest types. Our studies used average values to estimate seasonality. FAL values (Fig. 4) reflect the likelihood of finding the species in fruit over 40 years (1978-2018), but the actual FAL values in any given year could be much more pronounced. Three phenological field studies in the Distrito Federal that recorded fruiting of fifteen of our typical species during a single, or sometimes two consecutive fruiting seasons (Proença \& Gibbs 1994; Antunes \& Ribeiro 1999; Horstmann 2015) were compared to the herbarium record. Herbarium data showed that these 15 species were found in fruit between 8-12 months of the year ( $x=10.5$ months) over 40 years; field-based phenology data, however, showed that these same species, during any given season, were in fruit between 1-12 months ( $x=2.9$ months); if we remove the outlier Magnolia ovata, whose large woody fruits take a year to mature, then the field fruiting range is between 1-6 months. Field records did, however, confirm seasonality in all cases in which we were able to attribute season. In most cases, field records also matched the season of the month of the highest probability when differences between high and low phenological predictability index (PPI) values were too close and the species was considered as season not defined. Interestingly, in three out of the four cases in which the season of the field record did not match our maximum PPI month, the species appears to be a supra-annual fruit producer: Cecropia pachystachya, Protium heptaphyllum, and Pera glabrata showed this pattern (17-month study; Horstmann 2015). Another aspect to be considered is that herbarium records that state that a species is in fruit may apply to both mature and immature fruit; thus, periods of mature fruit could be shorter than fruiting periods in the herbarium record. This would tend to affect plant species that take more than a month after flowering for the first mature fruits to appear, since PPI are based on monthly scores. Conversely, the herbarium record is probably biased towards mature fruits, since plants with mature fleshy fruits may be more likely to be collected than those with immature fruit (Cavallin et al. 2016).

Proving or disproving trade-off between species composition, species abundance and species seasonality would need long term field studies of gallery forest fruiting phenology (probably of three years or more) with gallery forests chosen based on their contrasting floristic compositions. Recording the periods of mature fruit, as well as estimating available pulp biomass, as was done by Staggemeier et al. (2017) for the Atlantic Forest could further refine the results.

\section{Conclusion}

The resources available to the fauna differed spatially following tree species composition, abundance and fruit availability in time as initially hypothesized. In this way, the spatial variation in the diversity of available food resources among the gallery forests found in this study may be even more important for the fauna during the dry season, when few fleshy-fruited tree species are fruiting in some sites. Differences in species composition and abundance among the forests would thus compensate for local reductions in food resources, which reinforce the need to conserve different gallery forest stands (Stevenson et al. 2015). Although the spatial and temporal variation in abundance of fleshy-fruited trees among gallery forests may contribute to landscape-scale diversity and fleshy fruit availability for the local fauna (Emer et al. 2018), the isolation of these forests in fragmented landscapes can hinder animal movement and the dispersal of diaspores between them, thus potentially decreasing plant recruitment (Correa et al. 2015). Our results may aid in the selection of trees for restoration of riparian vegetation that enhances the persistence of plant and animal species at landscape and regional scales. Hyper-abundant fleshy-fruited species that are more likely to fruit in the dry season (e.g., Virola sebifera) should be prioritized in forest restoration initiatives to increase food supply for frugivores during low FAL periods. Fleshy-fruited species that are ubiquitous in the studied gallery forests and fruit throughout the year (e.g., Cheiloclinium cognatum, Protium spruceanum, Richeria grandis, Tapirira guianensis and Xylopia emarginata) should also be considered, since they may represent a continuous source of food for frugivores. The low similarity in fleshy-fruited tree species found in the ten gallery forests, in a small region of the Cerrado serves as reinforcement for public conservation policies to protect these pathches of depleted tropical rainforest that run through the Brazilian savanna (Rodrigues et al. 2011).

\section{Acknowledgements}

We thank Dr. Bruno M. T. Walter for providing the raw data from the Riacho Fundo forest at Fazenda Sucupira, which allowed us to select species with DBH $\geq 5 \mathrm{~cm}$. 


\section{Adriano Antonio Brito Darosci, Frederico Scherr Caldeira Takahashi, Carolyn Elinore Barnes Proença, Lucia Helena Soares-Silva and Cássia Beatriz Rodrigues Munhoz}

\section{References}

Alencar A, Shimbo JZ, Lenti F, et al. 2020. Mapping three decades of changes in the Brazilian savanna native vegetation using Landsat data processed in the Google Earth Engine platform. Remote Sens 12: 924. doi:10.3390/rs12060924

Almeida-Neto M, Campassi F, Galetti M, Jordano P, Oliveira-Filho A. 2008. Vertebrate dispersal syndromes along the atlantic forest: Broadscale patterns and macroecological correlates. Global Ecology and Biogeography 17: 503-513.

Antunes NB, Ribeiro JF. 1999. Aspectos fenológicos de seis espécies vegetais em matas de galeria do Distrito Federal. Pesquisa Agropecuária Brasileira 34: 1517-1527.

Bierzychudek P, Eckhart V. 1988. Spatial segregation of the sexes of dioecious plants. The American Naturalist 132: 34-43.

Blendinger PG, Ruggera RA, Montellano MGN, et al. 2012. Fine-tuning the fruit-tracking hypothesis: Spatiotemporal links between fruit availability and fruit consumption by birds in andean mountain forests. Journal of Animal Ecology 81: 1298-1310.

Borges PA, Franke J, Santos Silva FD, Weiss H, Bernhofer C. 2014 Differences between two climatological periods (2001-2010 vs. 1971-2000) and trend analysis of temperature and precipitation in Central Brazil. Theoretical and Applied Climatology 116: 191-202.

Cavalcanti RB. 1992. The importance of forest edges in the ecology of open country cerrado birds. In: Furley PA, Proctor J, Ratter JA. (eds.) The nature and dynamics of forest-savanna boundaries. London, Chapman and Hall. p. 513-517.

Cavallin EKS, Munhoz CBR, Harris SA, Villarroel D, Proença CEB. 2016. Influence of biological and social-historical variables on the time taken to describe an angiosperm. American Journal of Botany 103: 2000-2012.

Chao A, Gotelli NJ, Hsieh TC, et al. 2014. Rarefaction and extrapolation with hill numbers: A framework for sampling and estimation in species diversity studies. Ecological Monographs 84: 45-67.

Condit R, Pitman N, Leigh EG, et al. 2002. Beta-diversity in tropical forest trees. Science 295: 666-669.

Correa DF, Álvarez E, Stevenson PR. 2015. Plant dispersal systems in neotropical forests: Availability of dispersal agents or availability of resources for constructing zoochorous fruits? Global Ecology and Biogeography 24: 203-214.

Darosci AAB, Bruna EM, Motta-Junior JC, Ferreira CDS, Blake JG, Munhoz CBR. 2017. Seasonality, diaspore traits and the structure of plantfrugivore networks in neotropical savanna forest. Acta Oecologica 84: 15-22.

Eiten G. 1972. The cerrado vegetation of Brazil. The Botanical Review 38: 201-341.

Emer C, Galetti M, Pizo MA, et al. 2018. Seed-dispersal interactions in fragmented landscapes-a metanetwork approach. Ecology Letters 21: 484-493.

Flora do Brasil 2020. 2020. Jardim Botânico do Rio de Janeiro. http:// floradobrasil.jbrj.gov.br/reflora/floradobrasil. 28 Aug. 2020.

Gouveia GP, Felfili JM. 1998. Fenologia de comunidades de cerrado e de mata de galeria no brasil central. Revista Árvore 22: 443-450.

Griz LMS, Machado ICS. 2001. Fruiting phenology and seed dispersal syndromes in caatinga, a tropical dry forest in the northeast of Brazil. Journal of Tropical Ecology 17: 303-321.

Guarino EDSG, Walter BMT. 2005. Fitossociologia de dois trechos inundáveis de matas de galeria no Distrito Federal, Brasil. Acta Botanica Brasilica 19: 431-442.

Guitián J, Munilla I. 2008. Resource tracking by avian frugivores in mountain habitats of northern spain. Oikos 117: 265-272.

Horstmann N. 2015. Composição florística e aspectos fenológicos de um fragmento de mata de galeria com vistas à restauração ecológica no cerrado, Distrito Federal. Graduation Thesis, Universidade de Brasília, Brasília.

Jara-Guerrero A, Cruz MDl, Méndez M. 2011. Seed dispersal spectrum of woody species in south ecuadorian dry forests: Environmental correlates and the effect of considering species abundance. Biotropica 43: $722-730$
Karr JR. 1976. Seasonality, resource availability, and community diversity in tropical bird communities. The American Naturalist 110: 973-994.

Kuhlmann M, Ribeiro JF. 2016. Fruits and frugivores of the brazilian cerrado: Ecological and phylogenetic considerations. Acta Botanica Brasilica 30: 495-507.

Legendre P, Legendre L. 2012. Numerical ecology. 3rd. edn. Amsterdam, London, Elsevier.

López-Martínez JO, Sanaphre-Villanueva L, Dupuy JM, HernándezStefanoni JL, Meave JA, Gallardo-Cruz JA. 2013. B-diversity of functional groups of woody plants in a tropical dry forest in yucatan. PLOS ONE 8: e73660. doi: 10.1371/journal.pone.0073660

Maruyama PK, Melo C, Pascoal C, et al. 2019. What is on the menu for frugivorous birds in the Cerrado? Fruiting phenology and nutritional traits highlight the importance of habitat complementarity. Acta Botanica Brasilica 33: 572-583.

Mendonça RC, Felfili JM, Walter BMT, et al. 2008. Flora vascular do cerrado. In: Sano SM, Almeida SP. (eds.) Cerrado: Ambiente e flora. Planaltina, EMBRAPA-CPAC. p. 417-1279.

Mendoza I, Peres CA, Morellato LPC. 2017. Continental-scale patterns and climatic drivers of fruiting phenology: A quantitative neotropical review. Global and Planetary Change 148: 227-241.

Morales JM, García D, Martínez D, Rodriguez-Pérez J, Herrera JM. 2013. Frugivore behavioural details matter for seed dispersal: A multi-species model for cantabrian thrushes and trees. PLOS ONE 8: e65216. doi: 10.1371/journal.pone.0065216

Murphy SJ, Audino LD, Whitacre J, et al. 2015. Species associations structured by environment and land-use history promote betadiversity in a temperate forest. Ecology 96: 705-715.

Negret Á. 1988. Fluxos migratórios na avifauna da reserva ecológica do IBGE, Brasília, DF, Brasil. Revista Brasileira de Zoologia 5: 209-214.

Oksanen J. 2011. Multivariate analysis of ecological communities in R: Vegan tutorial. R package version 1: 1-43. https://www. researchgate.net/profile/Cesar-Cardenas-6/post/Can_anyone_ help_me_in_understanding_and_clearly_interpreting_ANOSIM_ Analysis_of_Similarityand_SIMPER_Similarity_percentage_ analysisresults/attachment/59d62951c49f478072e9c30d/AS\% 3A272468734873601\%401441973016395/download/vegantutor.pdf.

Oliveira PEAM, Paula FR. 2001. Fenologia e biologia reprodutiva de plantas de matas de galeria. In: Ribeiro JF, Fonseca CEL, Sousa-Silva JC. (eds.) Cerrado: Caracterização e recuperação de matas de galeria. Planaltina, EMBRAPA-CPAC. p. 303-332.

Oliveira-Filho AT. 1989. Composição florística e estrutura comunitária da floresta de galeria do córrego da paciência, Cuiabá, (MT). Acta Botanica Brasilica 3: 91-112.

Oliveira-Filho AT, Ratter JA. 1995. A study of the origin of central brazilian forests by the analysis of plant species distribution patterns. Edinburgh Journal of Botany 52: 141-194.

Pessoa MS, Rocha-Santos L, Talora DC, et al. 2016. Fruit biomass availability along a forest cover gradient. Biotropica 49: 45-55.

Pijl LVD. 1982. Principles of dispersal in higher plants. 3rd. rev. and exp. edn. Berlin, New York, Springer-Verlag.

Pinheiro F, Ribeiro JF. 2001. Síndromes de dispersão de sementes em matas de galeria do distrito federal. In: Ribeiro JF, Fonseca CEL, Sousa-Silva JC. (eds.) Cerrado: Caracterização e recuperação de matas de galeria. Planaltina, EMBRAPA-CPAC. p. 335-375.

Polansky L, Boesch C. 2013. Long-term changes in fruit phenology in a west african lowland tropical rain forest are not explained by rainfall. Biotropica 45: 434-440.

Proença CEB, Filer DL, Lenza E, Silva JS, Harris SA. 2012. Phenological predictability index in Brahms: A tool for herbarium-based phenological studies. Ecography 35: 289-293.

Proença CEB, Gibbs PE. 1994. Reproductive biology of eight sympatric Myrtaceae from Central Brazil. New Phytologist 126: 343-354.

Proença CEB, Munhoz CBR, Jorge CL, Nóbrega MGG. 2001. Listagem e nível de proteção das espécies de fanerógamas do distrito federal, brasil. In: Cavalcanti TB, Ramos AE. (eds.) Flora do distrito federal. Brasília, EMBRAPA - Recursos Genéticos e Biotecnologia. p. 89-359. 


\section{Does spatial and seasonal variability in fleshy-fruited trees affect fruit availability? A case study in gallery forests of Central Brazil}

Ribeiro JF, Walter BMT. 2008. As principais fitofisionomias do bioma cerrado. In: Sano SM, Almeida SP, Ribeiro JF. (eds.) Cerrado: Ecologia e flora. Planaltina, EMBRAPA-CPAC. p. 151-212.

Rodrigues RR, Gandolfi S, Nave AG, et al. 2011. Large-scale ecological restoration of high-diversity tropical forests in se brazil. Forest Ecology and Management 261: 1605-1613.

Sampaio AB, Walter BMT, Felfili JM. 2000. Diversidade e distribuição de espécies arbóreas em duas matas de galeria na micro-bacia do riacho fundo, Distrito Federal. Acta Botanica Brasilica 14: 197-214.

Silva FAM, Assad EA, Evangelista BA. 2008. Caracterização climática do bioma cerrado. In: Sano SM, Almeida SP. (eds.) Cerrado: Ambiente e flora. Planaltina, EMBRAPA-CPAC. p. 69-88.

Silva-Júnior MC, Felfili JM, Walter BMT, et al. 2001. Análise da flora arbórea de matas de galeria no distrito federal: 21 levantamentos. In: Ribeiro JF, Fonseca CEL, Sousa-Silva JC. (eds.) Cerrado: Caracterização e recuperação de matas de galeria. Planaltina, EMBRAPA-CPAC. p. 143-191.

Staggemeier VG, Cazetta E, Morellato LPC. 2017. Hyperdominance in fruit production in the brazilian atlantic rain forest: The functional role of plants in sustaining frugivores. Biotropica 49: 71-82.

Stevenson PR, Link A, González-Caro S, Torres-Jiménez MF. 2015. Frugivory in canopy plants in a western amazonian forest: Dispersal systems, phylogenetic ensembles and keystone plants. PLOS ONE 10: e0140751. doi: 10.1371/journal.pone.0140751

ter Steege Ht, Pitman NCA, Sabatier D, et al. 2013. Hyperdominance in the amazonian tree flora. Science 342: 1243092. doi: 10.1126/ science. 1243092

Valenta K, Nevo O. 2020. The dispersal syndrome hypothesis: How animals shaped fruit traits, and how they did not. Functional Ecology 34: 1158-1169.

Veneklaas EJ, Fajardo A, Obregon S, Lozano J. 2005. Gallery forest types and their environmental correlates in a colombian savanna landscape. Ecography 28: 236-252.

Vieira FM, Purificação KN, Castilho LDS, Pascotto MC. 2013. Estrutura trófica da avifauna de quatro fitofisionomias de cerrado no parque estadual da serra azul. Ornithologia 5: 43-57.

Wang BC, Smith TB. 2002. Closing the seed dispersal loop. Trends in Ecology and Evolution 17: 379-386.

Whelan CJ, Schmidt KA, Steele BB, Quinn WJ, Dilger S. 1998. Are birdconsumed fruits complementary resources? Oikos 83: 195-205.

Wright SJ, Muller-Landau HC, Calderón O, Hernandéz A. 2005. Annual and spatial variation in seedfall and seedling recruitment in a neotropical forest. Ecology 86: 848-860. 